\title{
Influence of various levels of milk by-products in weaner diets on growth performance, blood urea nitrogen, diarrhea incidence, and pork quality of weaning to finishing pigs
}

\author{
S. H. Yoo ${ }^{1}$, J. S. Hong ${ }^{1}$, H. B. Yoo ${ }^{1}$, T. H. Han ${ }^{1}$, J. H. Jeong ${ }^{1}$, and Y. Y. Kim ${ }^{1, *}$
}

\begin{abstract}
* Corresponding Author: Y. Y. Kim
Tel: +82-2-880-4801, Fax: +82-2-878-5839,

E-mail: yooykim@snu.ac.kr
\end{abstract}

'School of Agricultural Biotechnology, College of Agricultural Life Sciences, Seoul National University, Seoul 08826, Korea

ORCID

S. H. Yoo

https://orcid.org/0000-0002-9626-9332

J. S. Hong

https://orcid.org/0000-0002-3401-3024

H. B. Yoo

https://orcid.org/0000-0002-3529-2459

T. H. Han

https://orcid.org/0000-0003-0801-4442

J. H. Jeong

https://orcid.org/0000-0001-9611-3787

Y. Y. Kim

https://orcid.org/0000-0001-8121-3291

Submitted Oct 27, 2016; Revised Feb 21, 2017; Accepted Nov 1, 2017
Objective: This study was conducted to evaluate various levels of milk by-product in weaning pig diet on growth performance, blood profiles, carcass characteristics and economic performance for weaning to finishing pigs.

Methods: A total of 160 weaning pigs ([Yorkshire $\times$ Landrace] $\times$ Duroc), average $7.01 \pm 1.32 \mathrm{~kg}$ body weight (BW), were allotted to four treatments by BW and sex in 10 replications with 4 pigs per pen in a randomized complete block design. Pigs were fed each treatment diet with various levels of milk by-product (Phase 1: $0 \%, 10 \%, 20 \%$, and $30 \%$, Phase 2: $0 \%, 5 \%, 10 \%$, and $15 \%$, respectively). During weaning period ( 0 to 5 week), weaning pigs were fed experimental diets and all pigs were fed the same commercial feed during growing-finishing period (6 to 14 week).

Results: In the growth trial, BW, average daily gain (ADG), and average daily feed intake (ADFI) in the nursery period ( 5 weeks) increased as the milk by-product level in the diet increased (linear, $\mathrm{p}<0.05$ ). Linear increases of pig BW with increasing the milk product levels were observed until late growing period (linear, $p=0.01$ ). However, there were no significant differences in $\mathrm{BW}$ at the finishing periods, $\mathrm{ADG}, \mathrm{ADFI}$, and gain:feed ratio during the entire growing-finishing periods. The blood urea nitrogen concentration had no significant difference among dietary treatments. High inclusion level of milk by-product in weaner diet decreased crude protein (quadratic, $\mathrm{p}=0.05$ ) and crude ash (Linear, $\mathrm{p}=0.05$ ) of Longissimus muscle. In addition, cooking loss and water holding capacity increased with increasing milk product levels in the weaner diets (linear, $\mathrm{p}<0.01 ; \mathrm{p}=0.05$ ). High milk by-product treatment had higher feed cost per weight gain compared to non-milk by-products treatment (linear, $\mathrm{p}=0.01$ ).

Conclusion: Supplementation of $10 \%$ to $5 \%$ milk by-products in weaning pig diet had results equivalent to the $30 \%$ to $15 \%$ milk treatment and $0 \%$ milk by-product supplementation in the diet had no negative influence on growth performance of finishing pigs.

Keywords: Economic Analysis; Growing-finishing Pig; Growth Performance; Milk By-products; Weaning Pig

\section{INTRODUCTION}

Generally, not only corn and soybean meal (SBM) but also lactose and whey powder are also main feed ingredients in weaning pigs diet in Korea. It is well known that lactose and whey powder are used as the main raw materials in weaning pig diets and that supplementation of milk by-products helps maintain an enhanced intestinal environment [1]. Moreover, lactose effects growth and enhances feed intake in weaning pig diets [2-4]. However, according to U.S. Department of Agriculture, international price trends for dairy products are very unstable, and their price is expensive compared to grains. Therefore weaning pig diets which 
contain high levels of milk by-products are expensive and cause an increase in the cost of pork production. Recent studies indicated that growth performance of weaning pigs was increased by increasing dietary lactose in early weaning period [3-6].

Recently, Jin [7] reported an evaluation of supplementation with barley instead of milk by-products in weaning pig's diet. This demonstrated that barley replacing milk by-product caused low growth performance during the weaning period. However, growth of growing and finishing pigs in the barley treatment caught up with pigs in the milk by-product treatment, resulting in similar days to market weight. For this reason, current study was conducted to understand the effects of various levels of milk by-product in weaning pig diet on growth performance and blood profiles, thereafter growth, carcass characteristics and economics analysis in growingfinishing pigs.

\section{MATERIALS AND METHODS}

\section{Experimental design and diet}

All experimental procedures involving animals were conducted in accordance with the Animal Experimental Guidelines provided by the Seoul National University Institutional Animal Use and Care Committee (SNUIAUCC; SNU-160513-1).

A total of 160 weaning pigs ([Yorkshire $\times$ Landrace $] \times$ Duroc), $7.01 \pm 1.32 \mathrm{~kg}$ initial body weight (BW), were used in a 19 week feeding trial. Pigs were allotted to four treatments based on BW and sex in 10 replications with 4 pigs per pen in a randomized complete block design.

Dietary treatments were: i) Non: corn-SBM based diet+milk by-product $0 \%$ (Phases 1 and 2: whey powder and lactose $0 \%$ ), ii) Low: basal diet+milk by-product $10 \%$ to $5 \%$ (Phase 1 : whey powder $4 \%$ and lactose $6 \%$, Phase 2 : whey powder $2 \%$ and lactose 3\%), iii) Medium: basal diet+milk by-product 20\% to $10 \%$ (Phase 1: whey powder $8 \%$ and lactose $12 \%$, Phase 2 : whey powder $4 \%$ and lactose $6 \%$ ), iv) High: basal diet+milk byproduct $30 \%$ to $15 \%$ (Phase 1: whey powder $12 \%$ and lactose $18 \%$, Phase 2 : whey powder $6 \%$ and lactose $9 \%$ ). Those experimental diets were fed during the weaning period ( 0 to 5 week). All nutrients met or exceeded the requirement estimates of NRC [8]. The formula and chemical compositions of weaning pigs' diets are presented in Tables 1 and 2. After weaning period (5 weeks), all pigs were fed a common commercial feed during the entire growing-finishing period (14 weeks). Earlygrowing diet had metabolizable energy (ME) 3,277 kcal/kg, crude protein (CP) $16.4 \%$, total lysine $0.98 \%$, late-growing diet had ME 3,274 kcal $/ \mathrm{kg}$, CP $15.24 \%$, total lysine $0.93 \%$, earlyfinishing diet had ME 3,279 kcal/kg, CP $14.11 \%$, total lysine $0.86 \%$, late-finishing diet had ME 3,280 kcal $/ \mathrm{kg}, \mathrm{CP} 12.53 \%$, total lysine $0.74 \%$. The chemical composition of commercial diets during growing-finishing period are presented in Table 3.
Table 1. Formula and chemical composition of the experimental diets in phase 1 (0 to 2 wks)

\begin{tabular}{|c|c|c|c|c|}
\hline \multirow{2}{*}{ Item } & \multicolumn{4}{|c|}{ Treatments ${ }^{1)}$} \\
\hline & Non & Low & Medium & High \\
\hline \multicolumn{5}{|l|}{ Ingredients (\%) } \\
\hline Corn & 38.93 & 28.79 & 18.61 & 8.51 \\
\hline Soybean meal & 37.62 & 38.30 & 38.98 & 39.64 \\
\hline Wheat bran & 1.76 & 1.72 & 1.71 & 1.68 \\
\hline Whey powder ${ }^{2)}$ & 0.00 & 4.00 & 8.00 & 12.00 \\
\hline Lactose $^{3)}$ & 0.00 & 6.00 & 12.00 & 18.00 \\
\hline Fish meal & 2.83 & 2.83 & 2.83 & 2.83 \\
\hline Barley & 10.13 & 10.13 & 10.13 & 10.13 \\
\hline Palm kernel meal & 3.00 & 3.00 & 3.00 & 3.00 \\
\hline Soy-oil & 2.76 & 2.38 & 2.01 & 1.61 \\
\hline Monodicalcium phosphate & 1.43 & 1.40 & 1.37 & 1.32 \\
\hline Limestone & 0.71 & 0.65 & 0.59 & 0.53 \\
\hline L-lysine $\cdot \mathrm{HCl}$ & 0.16 & 0.13 & 0.09 & 0.06 \\
\hline DL-methionine & 0.02 & 0.02 & 0.03 & 0.04 \\
\hline Vit. Mix & 0.10 & 0.10 & 0.10 & 0.10 \\
\hline Min. Mix & 0.10 & 0.10 & 0.10 & 0.10 \\
\hline Salt & 0.20 & 0.20 & 0.20 & 0.20 \\
\hline Choline-Cl (50\%) & 0.10 & 0.10 & 0.10 & 0.10 \\
\hline $\mathrm{ZnO} 0^{6)}$ & 0.10 & 0.10 & 0.10 & 0.10 \\
\hline$\beta$-Mannanase ${ }^{7)}$ & 0.05 & 0.05 & 0.05 & 0.05 \\
\hline Total & 100.00 & 100.00 & 100.00 & 100.00 \\
\hline \multicolumn{5}{|l|}{ Chemical composition } \\
\hline Dry matter ${ }^{8)}(\%)$ & 90.68 & 90.34 & 91.55 & 92.41 \\
\hline Crude protein $^{8)}(\%)$ & 23.90 & 23.73 & 23.32 & 23.49 \\
\hline Crude fat ${ }^{8)}(\%)$ & 3.93 & 3.55 & 3.18 & 2.98 \\
\hline Crude $\operatorname{ash}^{8)}(\%)$ & 6.91 & 7.09 & 6.89 & 7.08 \\
\hline Metabolizable energy ${ }^{9)}(\mathrm{kcal} / \mathrm{kg})$ & $3,265.00$ & $3,265.06$ & $3,265.09$ & $3,265.00$ \\
\hline Lysine $^{9)}(\%)$ & 1.35 & 1.35 & 1.35 & 1.35 \\
\hline Methionine ${ }^{9)}(\%)$ & 0.35 & 0.35 & 0.35 & 0.35 \\
\hline $\mathrm{Ca}^{9)}(\%)$ & 0.80 & 0.80 & 0.80 & 0.80 \\
\hline $\mathrm{P}^{9)}(\%)$ & 0.65 & 0.65 & 0.65 & 0.65 \\
\hline \multicolumn{5}{|c|}{ 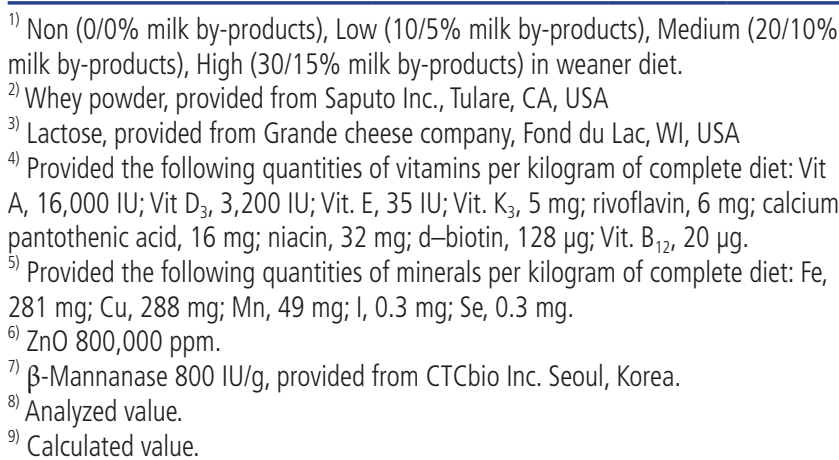 } \\
\hline
\end{tabular}

\section{Feeding trial}

All pigs were housed in an environmentally controlled building with half-slotted concrete floors and each pen equipped with a feeder and a nipple drinker to provide ad-libitum access. The BW and feed intake were recorded at $0,2,5,9,13,17$, and 19 week to calculate the average daily gain (ADG), average daily feed intake (ADFI), and gain:feed (G:F) ratio. 
Table 2. Formula and chemical composition of the experimental diets in phase2 (3 to 5 wks)

\begin{tabular}{|c|c|c|c|c|}
\hline \multirow{2}{*}{ Item } & \multicolumn{4}{|c|}{ Treatments $^{1)}$} \\
\hline & Non & Low & Medium & High \\
\hline \multicolumn{5}{|l|}{ Ingredients (\%) } \\
\hline Corn & 45.64 & 40.46 & 35.26 & 30.06 \\
\hline Soybean meal & 30.06 & 30.23 & 30.41 & 30.56 \\
\hline Wheat bran & 1.98 & 2.12 & 2.28 & 2.48 \\
\hline Whey powder ${ }^{2)}$ & 0.00 & 2.00 & 4.00 & 6.00 \\
\hline Lactose $^{3)}$ & 0.00 & 3.00 & 6.00 & 9.00 \\
\hline Fish meal & 2.65 & 2.75 & 2.85 & 2.95 \\
\hline Barley & 12.00 & 12.00 & 12.00 & 12.00 \\
\hline Palm kernel meal & 3.00 & 3.00 & 3.00 & 3.00 \\
\hline Soy-oil & 2.16 & 2.00 & 1.84 & 1.68 \\
\hline Monodicalcium phosphate & 1.26 & 1.25 & 1.23 & 1.20 \\
\hline Limestone & 0.57 & 0.53 & 0.49 & 0.45 \\
\hline L-Lysine $\cdot \mathrm{HCl}$ & 0.13 & 0.11 & 0.09 & 0.07 \\
\hline DL-methionine & 0.00 & 0.00 & 0.00 & 0.00 \\
\hline Vit. Mix & 0.10 & 0.10 & 0.10 & 0.10 \\
\hline Min. Mix & 0.10 & 0.10 & 0.10 & 0.10 \\
\hline Salt & 0.20 & 0.20 & 0.20 & 0.20 \\
\hline Choline-Cl (50\%) & 0.10 & 0.10 & 0.10 & 0.10 \\
\hline $\mathrm{ZnO}$ & 0.00 & 0.00 & 0.00 & 0.00 \\
\hline$\beta$-Mannanase ${ }^{6)}$ & 0.05 & 0.05 & 0.05 & 0.05 \\
\hline Total & 100.00 & 100.00 & 100.00 & 100.00 \\
\hline \multicolumn{5}{|l|}{ Chemical composition } \\
\hline Dry matter ${ }^{7)}(\%)$ & 88.45 & 87.40 & 88.63. & 89.01 \\
\hline Crude protein $(\%)$ & 20.60 & 21.02 & 20.93 & 20.92 \\
\hline Crude fat ${ }^{7)}(\%)$ & 3.45 & 3.33 & 3.12 & 3.02 \\
\hline${\text { Crude } \operatorname{ash}^{71}(\%)}$ & 5.18 & 6.97 & 5.67 & 6.33 \\
\hline$M E^{8)}(\mathrm{kcal} / \mathrm{kg})$ & $3,265.00$ & $3,265.08$ & $3,265.07$ & $3,265.02$ \\
\hline Lysine $^{8)}(\%)$ & 1.15 & 1.15 & 1.15 & 1.15 \\
\hline Methionine $^{8)}(\%)$ & 0.30 & 0.30 & 0.31 & 0.31 \\
\hline$C a^{8)}(\%)$ & 0.70 & 0.70 & 0.70 & 0.70 \\
\hline$P^{8)}(\%)$ & 0.60 & 0.60 & 0.60 & 0.60 \\
\hline
\end{tabular}

1) Non (0/0\% milk by-products), Low (10/5\% milk by-products), Medium (20/10\% milk by-products), High (30/15\% milk by-products) in weaner diet.

${ }^{2)}$ Whey powder, provided from Saputo Inc., Tulare, CA, USA

${ }^{3)}$ Lactose, provided from Grande cheese company, Fond du Lac, WI, USA

4) Provided the following quantities of vitamins per kilogram of complete diet: Vit A, 16,000 IU; Vit $D_{3}, 3,200$ IU; Vit. E, 35 IU; Vit. $K_{3}, 5$ mg; rivoflavin, 6 mg; calcium pantothenic acid, 16 mg; niacin, 32 mg; d-biotin, $128 \mu$; Vit. $B_{12}, 20 \mu g$.

${ }^{5)}$ Provided the following quantities of minerals per kilogram of complete diet: $\mathrm{Fe}$, 281 mg; Cu, 288 mg; Mn, 49 mg; l, 0.3 mg; Se, 0.3 mg.

6) $\beta$-Mannanase $800 \mathrm{lU} / \mathrm{g}$, provided from CTCbio Inc. Seoul, Korea

${ }^{7)}$ Analyzed value.

${ }^{8)}$ Calculated value.

\section{Blood urea nitrogen}

Blood samples were collected from anterior vena cava of 6 pigs per treatment for measuring blood urea nitrogen (BUN) after 3 hours of fasting at 0, 2, 5, 9, 13, 17, and 19 weeks. Collected blood samples were centrifuged for $15 \mathrm{~min}$ by $1,700 \mathrm{~g}$ at $4^{\circ} \mathrm{C}$ (Eppendorf centrifuge 5810R, Hamburg, Germany). Then, sera samples were aspirated by pipette and stored at $-20^{\circ} \mathrm{C}$ until analysis. The BUN concentration was analyzed using
Table 3. Chemical composition of experimental diets in growing-finishing period (6 to 19 wks)

\begin{tabular}{lcccc}
\hline $\begin{array}{l}\text { Proximate } \\
\text { analysis } \\
(\%)\end{array}$ & $\begin{array}{c}\text { Early } \\
\text { growing } \\
\text { period } \\
(\mathbf{6 - 9} \mathbf{w k})\end{array}$ & $\begin{array}{c}\text { Last } \\
\text { growing } \\
\text { period } \\
(\mathbf{1 0 - 1 3} \mathbf{w k})\end{array}$ & $\begin{array}{c}\text { Early } \\
\text { finishing } \\
\text { period } \\
(\mathbf{1 4}-\mathbf{1 7} \mathbf{w k})\end{array}$ & $\begin{array}{c}\text { Last } \\
\text { finishing } \\
\text { period } \\
(\mathbf{1 8 - 1 9} \mathbf{w k})\end{array}$ \\
\hline Dry matter & 88.57 & 88.68 & 88.44 & 88.21 \\
Crude protein & 16.40 & 15.24 & 14.11 & 12.53 \\
Crude ash & 4.45 & 4.05 & 3.47 & 3.01 \\
Crude fat & 4.40 & 3.97 & 3.71 & 3.46 \\
\hline
\end{tabular}

1) Analyzed value.

analyzer (Ciba-Corning model, Express Plus, Ciba Corning Diagnostics Co., Basel, Switzerland).

\section{Diarrhea incidence}

Incidence of diarrhea was measured every 9:00 am for 35 days post weaning. Data were recorded by each pen and divided into 2 phases to assess the general pattern (Phase 1 and Phase 2). A score of diarrhea incidence from 0 to 4 score $(0=$ no evidence of watery diarrhea, $1=1$ pig showed evidence of watery diarrhea, $2=2$ pigs, $3=3$ pigs, and $4=$ all pigs $(n=4)$ showed evidence of watery diarrhea in the pen) was determined by counting pigs with evidence of watery diarrhea [9]. After recording data, evidence of watery diarrhea was cleaned away.

\section{Carcass characteristics}

Five pigs from each treatment were slaughtered at an average $113 \mathrm{~kg}$ for the carcass analysis at the end of experiment. Longissimus muscle (LM) samples were collected from nearby 10th rib on the right side of carcass. Because of chilling procedure, 30 minutes after slaughter was regarded as initial time $(0 \mathrm{~h})$. Longissimus muscle $\mathrm{pH}$ and color were measured at initial, 3, 6, 12, and $24 \mathrm{~h}$. The $\mathrm{pH}$ of LM was measured using a pH meter ( $\Phi 500$ Series, Bechman Coulter, S. Kraember Blvd Brea, CA, USA) and pork color was measured by Commission Internationale de l'Eclairage (CIE) color $\mathrm{L}^{*}, \mathrm{a}^{*}$, and $\mathrm{b}^{*}$ value using a CR300 spectrophotometer (Minolta Camera Co., Tokyo, Japan). Proximate analysis of LM samples was conducted by the method of AOAC [10].

Water holding capacity (WHC) of pork was measured by centrifuge method. Longissimus muscles were ground and sampled in filter tube, then heated in water bath at $80^{\circ} \mathrm{C}$ for $20 \mathrm{~min}$ and centrifuged for $10 \mathrm{~min}$ at $252 \mathrm{~g}$ and $10^{\circ} \mathrm{C}$ (Eppendorf centrifuge 5810R, Hamburg, Germany). For cooking loss analysis, LM samples were packed in a polyethylene bag and weighted then heated in water bath until core temperature reached $72^{\circ} \mathrm{C}$ and weighed again. After heated, samples were cored $\left(0.75 \mathrm{~cm}^{3}\right)$ parallel to muscle fiber and the cores were used to measure the shear force (Warner Bratzler Shear, Chichago, IL, USA). Cooking loss, shear force, and WHC of LM samples were analyzed by National Institute of Animal 
Science.

\section{Economic analysis}

Economic efficiency was calculated by feed intake, feed cost, and feed efficiency. The total feed cost (won) per weight gain $(\mathrm{kg})$ was calculated using G:F ratio and feed cost. In addition, calculation of estimated feed cost to $110 \mathrm{~kg}$ as follows;

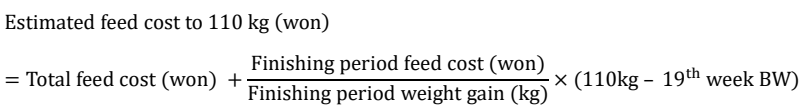

The days to market weight $(110 \mathrm{~kg})$ was estimated from 19th week as the end of feeding trial and added the estimated days by $\mathrm{ADG}$ of 17 to 19 weeks.

\section{Chemical analysis}

Diets were ground by a Cyclotec 1093 Sample Mill (Foss Tecator, Hillerod, Denmark) and then the contents analyzed; dry matter (procedure 967.03; AOAC [10]), crude ash (procedure 923.03; AOAC [10]) and crude fat (procedure 920.39; AOAC [10]). The nitrogen content was analyzed by using the Kjeldahl procedure with Kjeltec (KjeltecTM 2200, Foss Tecator, Höganäs, Sweden) and calculating the CP content (Nitrogen $\times 6.25$; procedure 981.10; AOAC [10]).

\section{Statistical analysis}

Statistical analysis was carried out by general linear model procedure of SAS [11] and orthogonal polynomial contrasts were used to determine linear and quadratic effects by increasing dietary milk by-products levels in weaning pig diet. For data on growth performance, diarrhea incidence, and economic analysis, each pen was considered as experimental unit, while individual pig was used as experimental unit for data on blood profile and carcass characteristics. The differences were declared significant at $\mathrm{p}<0.05$ or highly significant at $\mathrm{p}<0.01$ and the determination of tendency for all analysis was $0.05<\mathrm{p}<0.10$.

\section{RESULTS AND DISCUSSION}

\section{Growth performance}

The influence of various levels of milk by-products in weaning pig diet on growth performance during weaning to finishing pig period are presented in Table 4 and 5. During weaning period, BW, ADG, and ADFI increased linearly with increasing milk by-product levels in the weaner diets (linear, $\mathrm{p}<0.05$ ). The BW increased linearly at 5 and 13 weeks (linear, $\mathrm{p}<0.01$, $\mathrm{p}=0.01)$, ADG increased linearly with tendency during 10-13 weeks (linear, $p=0.09$ ) but decreased during 14-17 weeks (linear, $\mathrm{p}=0.08)$, ADFI increased linearly with tendency during 5-9 weeks (linear, $p=0.08$ ) and G:F ratio decreased quadratically during $14-17$ weeks (quadratic, $p=0.03$ ). The trend of
Table 4. Influence of various milk by-products levels in weaning pig diet on growth performance in weaning pigs ${ }^{1)}$

\begin{tabular}{|c|c|c|c|c|c|c|c|}
\hline \multirow{2}{*}{ Criteria } & \multicolumn{4}{|c|}{ Treatments $^{2)}$} & \multirow{2}{*}{ SEM } & \multicolumn{2}{|c|}{ p-value } \\
\hline & Non & Low & Medium & High & & Lin. & Quad. \\
\hline \multicolumn{8}{|c|}{ Body weight (kg) } \\
\hline Initial & 7.006 & 7.011 & 7.008 & 7.013 & 0.288 & - & - \\
\hline $2 w k$ & 11.59 & 12.36 & 12.21 & 12.64 & 0.502 & 0.04 & 0.59 \\
\hline $5 w k$ & 21.82 & 24.09 & 24.72 & 25.27 & 0.919 & $<0.01$ & 0.15 \\
\hline \multicolumn{8}{|l|}{ ADG (g) } \\
\hline $0-2 w k$ & 319 & 387 & 372 & 402 & 17.0 & 0.04 & 0.41 \\
\hline $3-5 w k$ & 487 & 558 & 596 & 601 & 23.1 & 0.01 & 0.23 \\
\hline $0-5 w k$ & 420 & 490 & 506 & 522 & 18.6 & $<0.01$ & 0.12 \\
\hline \multicolumn{8}{|l|}{ ADFI $(g)$} \\
\hline $0-2 w k$ & 436 & 474 & 503 & 507 & 21.7 & 0.01 & 0.40 \\
\hline $3-5 w k$ & 801 & 978 & 955 & 1,051 & 39.8 & $<0.01$ & 0.22 \\
\hline $0-5 w k$ & 655 & 776 & 774 & 834 & 31.6 & $<0.01$ & 0.19 \\
\hline \multicolumn{8}{|c|}{ Gain:feed ratio } \\
\hline $0-2 w k$ & 0.737 & 0.773 & 0.737 & 0.790 & 0.0158 & 0.40 & 0.81 \\
\hline $3-5 w k$ & 0.609 & 0.533 & 0.628 & 0.576 & 0.0201 & 0.98 & 0.75 \\
\hline $0-5 w k$ & 0.644 & 0.640 & 0.655 & 0.628 & 0.0140 & 0.88 & 0.60 \\
\hline
\end{tabular}

SEM, standard error of the mean.

${ }^{1)} \mathrm{A}$ total 160 crossbred pigs was fed from average initial body $7.01 \pm 1.32 \mathrm{~kg}$ and the average final body weight was $23.97 \mathrm{~kg}$.

${ }^{2)}$ Non (0/0\% milk by-products), Low (10/5\% milk by-products), Medium (20/10\% milk by-products), High (30/15\% milk by-products) in weaner diet.

weaning phase was continued until the end of 13 week, thereafter there was no significant difference in growth performance among treatments. However, G:F ratios both in weaning and growing-finishing period were not affected by dietary milk by-products treatment.

In the current study, pigs fed the diets containing high level of milk products had greater BW, ADG, and ADFI during weaning period, because the gastrointestinal tract of the newly weaned pig is easily adapted to a milk based diet as a result of high lactase activity $[12,13]$. Numerous researches reported that the beneficial effects of high dietary lactose improved growth performance of pigs in early weaning phase [3,5,14-16]. In addition, high dietary lactose improved initial stimulation of appetite and feed intake $[4,6]$. The growth response in BW to dietary treatment continued until late growing period (13 week). However, differences in growth performance during the weaning period disappeared and significant difference was not observed among treatments at the end of experiment (19 week). Shearer and Dunkin [17] demonstrated that growth of pigs could be improved by high levels of dietary lactose $(30 \%$ or $45 \%$ but subsequent growing-finishing pigs grew slower than those fed low lactose diet ( $0 \%$ or $15 \%)$. Tokach et al [18] also reported that different levels of milk by-product $(0 \%$ or $40 \%$ ) in weaning pig diets produced significant differences in growth performance only during the weaning period and any significant difference was not observed in growth performance during the growing-finishing. Also, growth retardation due 
Table 5. Influence of various milk by-products levels in weaning pig diet on growth performance in growing-finishing pigs ${ }^{1)}$

\begin{tabular}{|c|c|c|c|c|c|c|c|}
\hline \multirow{2}{*}{ Criteria } & \multicolumn{4}{|c|}{ Treatments ${ }^{2)}$} & \multirow{2}{*}{ SEM } & \multicolumn{2}{|c|}{$p$-value } \\
\hline & Non & Low & Medium & High & & Lin. & Quad. \\
\hline \multicolumn{8}{|c|}{ Body weight (kg) } \\
\hline 5 wk & 21.82 & 24.09 & 24.72 & $25.27 \mathrm{~A}$ & 0.919 & $<0.01$ & 0.15 \\
\hline 9 wk & 40.87 & 45.84 & 44.95 & 44.62 & 1.117 & 0.12 & 0.35 \\
\hline 13 wk & 66.03 & 73.62 & $73.00 \mathrm{a}$ & 73.73 & 1.312 & 0.01 & 0.07 \\
\hline 17 wk & 89.67 & 95.49 & 91.88 & 93.01 & 1.467 & 0.59 & 0.38 \\
\hline $19 w k$ & 105.41 & 112.10 & 109.87 & 109.71 & 1.806 & 0.47 & 0.31 \\
\hline \multicolumn{8}{|l|}{ ADG (g) } \\
\hline 6-9 wk & 681 & 777 & 723 & 691 & 25.2 & 0.91 & 0.17 \\
\hline 10-13 wk & 867 & 926 & 935 & 970 & 22.7 & 0.09 & 0.76 \\
\hline 14-17 wk & 877 & 841 & & 742 & 30.3 & 0.08 & 0.68 \\
\hline $18-19 w k$ & 926 & 977 & 1,058 & 982 & 42.3 & 0.56 & 0.51 \\
\hline 6-13 wk & 777 & 854 & 836 & 836 & 12.7 & 0.18 & 0.15 \\
\hline 14-19 wk & 896 & 895 & & 83 & 26.8 & 0.43 & 0.87 \\
\hline 6-19 wk & 828 & 871 & $\varepsilon$ & 836 & 15.4 & 0.99 & 0.45 \\
\hline 0-19 wk & 723 & 773 & 56 & 755 & 12.9 & 0.46 & 0.30 \\
\hline \multicolumn{8}{|l|}{ ADFI (g) } \\
\hline 6-9 wk & 1,655 & 2,017 & 1,853 & 1,955 & 62.6 & 0.08 & 0.16 \\
\hline 10-13 wk & 2,614 & 2,823 & 2,636 & 2,880 & 61.4 & 0.26 & 0.88 \\
\hline 14-17 wk & 2,719 & 2,976 & 2,678 & 2,584 & 100.3 & 0.49 & 0.44 \\
\hline 18-19 wk & 3,161 & 3,387 & & 3,079 & 104.2 & 0.71 & 0.43 \\
\hline 6-13 wk & 2,151 & 2,434 & 2,258 & 2,433 & 53.2 & 0.12 & 0.56 \\
\hline $14-19$ wk & 2,894 & 3,139 & 2,900 & 2,780 & 92.1 & 0.53 & 0.38 \\
\hline 6-19 wk & 2,467 & 2,734 & 2,532 & 2,581 & 57.9 & 0.79 & 0.36 \\
\hline 0-19 wk & 2,001 & 2,230 & 2,079 & 2,131 & 46.1 & 0.55 & 0.32 \\
\hline \multicolumn{8}{|l|}{ G:F ratio } \\
\hline 6-9 wk & 0.417 & 0.361 & & & & 0.17 & 0.66 \\
\hline 10-13 wk & 0.333 & 0.306 & 0.355 & 0.342 & 0.0096 & 0.39 & 0.71 \\
\hline 14-17 wk & 0.323 & 0.262 & 0.271 & 0.292 & 0.0086 & 0.26 & 0.03 \\
\hline 18-19 wk & 0.292 & 0.274 & 0.331 & 0.325 & 0.0040 & 0.26 & 0.84 \\
\hline 6-13 wk & 0.362 & 0.327 & 0.369 & 0.346 & 0.0077 & 0.95 & 0.73 \\
\hline 14-19 wk & 0.309 & 0.268 & 0.298 & 0.304 & 0.0090 & 0.85 & 0.24 \\
\hline 6-19 wk & 0.335 & 0.298 & 0.334 & 0.327 & 0.0078 & 0.90 & 0.39 \\
\hline $0-19$ wk & 0.362 & 0.324 & 0.365 & 0.357 & 0.0082 & 0.74 & 0.40 \\
\hline
\end{tabular}

SEM, standard error of the mean; $A D G$, average daily gain; $A D F I$, average daily feed intake; G:F, gain:feed.

${ }^{1)}$ A total 160 crossbred pigs was fed from average initial body $23.97 \mathrm{~kg}$ and the average final body weight was $109.2 \mathrm{~kg}$

${ }^{2)}$ Non (0/0\% milk by-products), Low (10/5\% milk by-products), Medium (20/10\% milk by-products), High (30/15\% milk by-products) in weaner diet.

to nutrient limitation in weaning pigs induced compensated growth of growing-finishing pigs resulting in similar BW at the end of finishing period $[19,20]$. Weaning pigs with low growth rate due to limited nutrient intake recovered the normal growth rate compared with other pigs on the same nutritional supply [21]. Ishida et al [20] reported that compensatory growth of pigs induced by lysine sufficiency was partly attributed to greater $\mathrm{N}$ retention which increased protein synthesis in skeletal muscle. In this way, pigs fed low milk byproduct diet had growth retardation compared with pigs fed high milk by-product diet, however, compensated growth occurred in growing-finishing period. In the present study, BW, ADG, and ADFI decreased in non or low level of milk by-product in the weaning diet, but this trend changed dramatically in the finishing period resulting in no significant difference of BW, ADG, ADFI, and G:F ratio at the end of late finishing period.

\section{Blood urea nitrogen}

The concentration of BUN has been used as a good indicator of maximal amino acid utilization [22]. It has been found that BUN is related directly to protein intake and inversely to protein quality $[23,24]$. In the current study, the concentration of BUN had no significant difference among treatments during whole experimental period except at 19 week where BUN concentrations tended to decrease with increasing milk by-product levels (linear, $\mathrm{p}=0.07$; Table 6 ). Dried milk or milk by-products were used as a protein source for young pigs were considered useful feed ingredients due to their nutrient composition, high digestibility, similarity to a sow's milk [12], and high lactase activity in weaning pig $[12,13]$. However, the current study demonstrated that protein utilization in pigs fed no or low levels of milk by-product did not differ from high milk by-products treatment.

\section{Diarrhea incidence}

The influence of various levels of milk by-products in weaning pig diet on diarrhea incidence is shown in Table 7. In weaning period, there was not any significant difference in the diarrhea incidence due to reduction of milk by-products in weaning pig's diet. Zinc oxide at pharmacological concentrations $(2,000$ to $3,000 \mathrm{mg} / \mathrm{kg}$ ) has been reported to reduce diarrhea during weaning period [25]. In current study, usage of zinc oxide in phase 1 diet was $800 \mathrm{ppm}$ and in phase 2 diet was $0 \mathrm{ppm}$. Also, barley has relatively high fiber source which reduced diarrhea occurrence and is helpful in preventing diarrhea [26]. Also, Jin [7] demonstrated that supplement of barley in weaning pig diet reduced the incidence of diarrhea. Due to the effect

Table 6. Influence of various milk by-products levels in weaning pig diet on blood urea nitrogen in weaning to finishing pigs ${ }^{1)}$

\begin{tabular}{ccccccccc}
\hline \multirow{2}{*}{ Criteria } & \multicolumn{3}{c}{ Treatments } & \multicolumn{2}{c}{ p-value } \\
\cline { 2 - 4 } \cline { 7 - 8 } & Non & Low & Medium & High & & & Lin. & Quad. \\
\hline Blood urea nitrogen & $(\mathrm{mg} / \mathrm{dL})$ \\
Initial & 14.0 & 15.2 & 14.6 & 15.0 & 0.46 & - & - \\
2 wk & 19.6 & 19.6 & 18.7 & 18.9 & 0.47 & 0.53 & 0.93 \\
5 wk & 14.8 & 14.9 & 15.3 & 12.7 & 0.65 & 0.36 & 0.37 \\
9 wk & 10.3 & 10.1 & 9.4 & 11.7 & 0.50 & 0.38 & 0.15 \\
13 wk & 11.7 & 11.2 & 9.8 & 10.1 & 0.33 & 0.11 & 0.28 \\
17 wk & 9.3 & 8.4 & 9.5 & 8.4 & 0.44 & 0.69 & 0.93 \\
19 wk & 10.7 & 10.9 & 9.2 & 7.3 & 0.66 & 0.07 & 0.45 \\
\hline
\end{tabular}

SEM, standard error of means.

1) Least squares means of 6 observations per treatment. 
Table 7. Influence of various milk by-products levels in weaning pig diet on diarrhea incidence in weaning pigs ${ }^{1)}$

\begin{tabular}{lllllllll}
\hline \multirow{2}{*}{ Criteria } & \multicolumn{5}{c}{ Treatments } & & \multicolumn{2}{c}{$p$-value } \\
\cline { 2 - 4 } & Non & Low & Medium & High & & & Lin. & Quad. \\
\hline Diarrhea incidence & & & & & & & \\
0-2 wk & 1.09 & 1.29 & 1.68 & 1.64 & 0.133 & 0.28 & 0.67 \\
3-5 wk & 0.57 & 0.49 & 0.45 & 0.66 & 0.064 & 0.69 & 0.32 \\
0-5 wk & 0.80 & 0.85 & 0.99 & 1.09 & 0.080 & 0.22 & 0.88 \\
\hline
\end{tabular}

SEM, standard error of means.

1) Least squares means of 10 replications per treatment.

${ }^{2)}$ Diarrhea incidence: 0 (no occurrence) to 4 (diarrhea on all pigs): Data were measured by average diarrhea incidence during each phases.

of $\mathrm{ZnO}$ and barley, weaning pigs fed no or low milk by-product had no significant difference in diarrhea incidence compared with pigs fed high milk by-product content.

\section{Pork quality}

The pork quality was measured in order to investigate how the reduction in milk by-product in weaner diets affects the pork quality after slaughter. In the present study, moisture and crude fat of LM had no significant differences among dietary treatments (Table 8). However, crude protein of LM had a quadratic response (quadratic, $\mathrm{p}=0.05$ ) and crude ash of LM had a linear response (linear, p 0.05). Frape et al [27] found that early growth rate of weaning pigs was influenced by dietary nutrients but it did not affect the chemical compositions of the carcass in finishing pigs. Although there were no significant differences in moisture and crude fat, high milk by-product treatment had low crude protein and crude ash content in LM. As the dietary milk by-product supplementation increased in weaning period, cooking loss was increased linearly (linear, $\mathrm{p}<0.01$ ) and WHC was decreased linearly (linear, $\mathrm{p}=0.05$ ). Also, shear force of LM tended to increase linearly with dietary milk byproduct content increased in weaning pig's diet (linear, $\mathrm{p}=$ 0.07). Beilken et al [28] demonstrated that shear force was increased when WHC decreased. Cooking loss is an indirect index of WHC because it decreases when WHC increases [29]. In addition, WHC is an important factor of pork quality [30,31] and high WHC improves pork quality [32,33]. Consequently these results demonstrated that pork quality of finishing pigs was improved when low milk by-products was provided in weaning pigs' diet.

In general, the $\mathrm{pH}$ change of pork is a critical factor that determines the quality of pork and it has an effect on freshness, WHC, tenderness, binding ability, meat color and texture [34]. Maganhini et al [35] reported that initial $\mathrm{pH}$ was regarded as an indication of PSE (pale, soft and exudative) pork and the final $\mathrm{pH}$ was acknowledged as an estimation of DFD (dark, firm and dry). The measured $\mathrm{pH}$ ( 0 hour to 24 hour) was not significantly different among treatments (Table 9) and $\mathrm{pH}$ of $\mathrm{LM}$ was in the normal range ( $\mathrm{pH} 5.5$ to $\mathrm{pH} 6.0$ ).

The result of pork color (CIE value) of LM is presented in Table 10. There were no significantly difference in a value, $L^{*}$, $\mathrm{a}^{*}$, and $\mathrm{b}^{*}$ value at $0,3,6,12,24 \mathrm{~h}$ after slaughter. In pork color, decreasing in redness and increasing in yellowness had a negative influence on the freshness of pork [36]. However, there were no change in redness or yellowness by milk by-products levels in weaning pig diets. Therefore, these results demonstrated that low levels of milk by-products in weaning pig diet had no negative influence on $\mathrm{pH}$ and color of pork after

Table 9. Influence of various milk by-products levels in weaning pig diet on $\mathrm{pH}$ of Longissimus muscle after slaughter ${ }^{1)}$

\begin{tabular}{|c|c|c|c|c|c|c|c|}
\hline \multirow{2}{*}{ Criteria } & \multicolumn{4}{|c|}{ Treatments } & \multirow{2}{*}{ SEM } & \multicolumn{2}{|c|}{ p-value } \\
\hline & Non & Low & Medium & High & & Lin. & Quad. \\
\hline \multicolumn{8}{|c|}{ Time after slaughter (h) } \\
\hline $\mathrm{Oh}$ & 5.72 & 5.77 & 5.75 & 5.68 & 0.046 & 0.71 & 0.54 \\
\hline $3 \mathrm{~h}$ & 5.49 & 5.51 & 5.50 & 5.50 & 0.018 & 0.89 & 0.37 \\
\hline $6 \mathrm{~h}$ & 5.63 & 5.62 & 5.52 & 5.63 & 0.028 & 0.68 & 0.20 \\
\hline $12 \mathrm{~h}$ & 5.64 & 5.62 & 5.53 & 5.65 & 0.025 & 0.56 & 0.21 \\
\hline $24 \mathrm{~h}$ & 5.69 & 5.63 & 5.51 & 5.63 & 0.028 & 0.23 & 0.06 \\
\hline
\end{tabular}

SEM, standard error of means.

${ }^{1)}$ Least squares means for five observations per treatment.

Table 8. Influence of various milk by-products levels in weaning pig diet on carcass chracteristics ${ }^{1)}$

\begin{tabular}{|c|c|c|c|c|c|c|c|}
\hline \multirow{2}{*}{ Criteria } & \multicolumn{4}{|c|}{ Treatments } & \multirow{2}{*}{ SEM } & \multicolumn{2}{|c|}{ p-value } \\
\hline & Non & Low & Medium & High & & Lin. & Quad. \\
\hline \multicolumn{8}{|l|}{ Proximate analysis (\%) } \\
\hline Moisture & 71.70 & 70.14 & 71.35 & 71.64 & 0.431 & 0.82 & 0.35 \\
\hline Crude protein & 21.53 & 21.62 & 22.41 & 20.69 & 0.236 & 0.37 & 0.05 \\
\hline Crude fat & 2.27 & 2.72 & 3.47 & 3.21 & 0.254 & 0.13 & 0.48 \\
\hline Crude ash & 1.46 & 1.46 & 1.19 & 1.13 & 0.066 & 0.05 & 0.85 \\
\hline \multicolumn{8}{|l|}{ Physiochemical property } \\
\hline Cooking loss (\%) & 34.10 & 30.59 & 35.05 & 37.08 & 0.608 & $<0.01$ & $<0.01$ \\
\hline Shear force $\left(\mathrm{kg} / 0.75 \mathrm{~cm}^{3}\right)$ & 6.67 & 6.49 & 6.85 & 7.45 & 0.167 & 0.07 & 0.23 \\
\hline WHC (\%) & 95.79 & 96.97 & 96.46 & 95.40 & 0.164 & 0.05 & $<0.01$ \\
\hline
\end{tabular}

SEM, standard error of means; WHC, water holding capacity.

1) Least squares means for five observations per treatment. 
Table 10. Influence of various milk by-products levels in weaning pig diet on meat color of Longissimus muscle after slaughter ${ }^{1)}$

\begin{tabular}{|c|c|c|c|c|c|c|c|}
\hline \multirow{2}{*}{ Criteria } & \multicolumn{4}{|c|}{ Treatments } & \multirow{2}{*}{ SEM } & \multicolumn{2}{|c|}{$p$-value } \\
\hline & Non & Low & Medium & High & & Lin. & Quad. \\
\hline \multicolumn{8}{|c|}{ CIE value, $\mathrm{L}^{2)}$} \\
\hline $\mathrm{Oh}$ & 41.49 & 41.89 & 43.19 & 42.33 & 0.546 & 0.51 & 0.61 \\
\hline $3 \mathrm{~h}$ & 41.46 & 42.46 & 43.38 & 42.62 & 0.670 & 0.54 & 0.58 \\
\hline $6 \mathrm{~h}$ & 42.81 & 44.56 & 45.45 & 44.50 & 0.676 & 0.41 & 0.40 \\
\hline $12 \mathrm{~h}$ & 43.84 & 45.33 & 46.83 & 46.00 & 0.609 & 0.19 & 0.38 \\
\hline $24 \mathrm{~h}$ & 45.25 & 46.61 & 48.36 & 46.97 & 0.516 & 0.16 & 0.20 \\
\hline \multicolumn{8}{|c|}{ CIE value, $a^{3)}$} \\
\hline $\mathrm{Oh}$ & 2.29 & 3.18 & 2.32 & 3.17 & 0.224 & 0.41 & 0.95 \\
\hline $3 \mathrm{~h}$ & 2.39 & 3.06 & 3.03 & 3.28 & 0.210 & 0.15 & 0.61 \\
\hline $6 \mathrm{~h}$ & 3.62 & 3.71 & 4.26 & 3.76 & 0.237 & 0.68 & 0.58 \\
\hline $12 \mathrm{~h}$ & 3.74 & 3.92 & 3.82 & 4.17 & 0.196 & 0.54 & 0.85 \\
\hline $24 \mathrm{~h}$ & 4.31 & 3.90 & 4.10 & 4.83 & 0.169 & 0.30 & 0.14 \\
\hline \multicolumn{8}{|c|}{ CIE value, $b^{4)}$} \\
\hline $\mathrm{Oh}$ & 4.60 & 5.12 & 4.93 & 5.23 & 0.187 & 0.37 & 0.82 \\
\hline $3 \mathrm{~h}$ & 4.65 & 5.47 & 5.59 & 5.55 & 0.210 & 0.14 & 0.28 \\
\hline $6 \mathrm{~h}$ & 5.86 & 6.13 & 6.93 & 6.36 & 0.232 & 0.36 & 0.44 \\
\hline $12 \mathrm{~h}$ & 6.00 & 6.35 & 6.68 & 6.75 & 0.197 & 0.23 & 0.76 \\
\hline $24 \mathrm{~h}$ & 6.44 & 6.41 & 7.10 & 7.25 & 0.153 & 0.20 & 0.94 \\
\hline
\end{tabular}

SEM, standard error of mean; CIE, Commission Internationale de I'Eclairage.

1) Least squares means for five observations per treatment.

${ }^{2)} L$, luminance or brightness (vary from black to white).

${ }^{3)} \mathrm{a}$, red $\cdot$ green component $(+a=\operatorname{red},-a=$ green).

${ }^{4)} b$, yellow $\cdot$ blue component $(+b=$ yellow, $-b=$ blue $)$.

slaughter.

\section{Economic analysis}

The influence of various level of milk by-product in weaning pig diet on feed cost per weight gain, days to market weight (reached $110 \mathrm{~kg} \mathrm{BW}$ ) and estimated feed cost to $110 \mathrm{~kg}$ are presented in Table 11. There were linear increases in feed cost per weight gain during 0 to 2 week, 3 to 5 week, 0 to 5 week, and 0 to 19 week (linear, $\mathrm{p}<0.01 ; \mathrm{p}<0.01 ; \mathrm{p}<0.01 ; \mathrm{p}<0.01$ ) as the dietary milk by-product supplementation was increased in weaning pigs' diet. Increasing feed cost of high milk byproducts treatment was mainly caused by milk by-products supplementation, since high price of milk by-products caused increasing feed cost of weaning pig diet. In addition, there was no significant difference in days to market weight because growth performance of late-finishing period (18 to 19 week) was not affected by dietary treatments. In estimated feed cost to $110 \mathrm{~kg}$, no significant difference was observed. However, estimated feed cost was reduced numerically as supplement of milk by-product in weaning pig diet decreased. Thus pigs fed lower milk by-products supplemented in weaning pig diet had greater economic profits.

\section{IMPLICATIONS}

Feeding of milk by-product in weaning pigs' diet increased growth performance during weaning period but its carry-over effect disappeared by the end of late finishing period. Also feeding high levels of milk by-products during the weaning period did not show a positive response in the marketing weight of pigs and no beneficial effects were observed in pork quality. Feed cost during whole experimental period could be reduced by about $11 \%$ when weaning pigs were fed no milk by-products treatment diet during weaning period. Consequently, supplementation of $10 \%$ to $5 \%$ milk by-products in weaning pigs' diet had results equivalent to the high milk treatment. Supplementation with non-milk by-products in the diet had no negative effects on growth performance of finishing

Table 11. Influence of various milk by-products levels in weaning pig diet on economic analysis in weaning to finishing pigs ${ }^{11}$

\begin{tabular}{|c|c|c|c|c|c|c|c|}
\hline \multirow{2}{*}{ Criteria } & \multicolumn{4}{|c|}{ Treatments } & \multirow{2}{*}{ SEM } & \multicolumn{2}{|c|}{$p$-value } \\
\hline & Non & Low & Medium & High & & Lin. & Quad. \\
\hline \multicolumn{8}{|l|}{ Feed cost per weight gain (won/kg) } \\
\hline $0-2 w k$ & 789 & 915 & 1,152 & 1,228 & 47.3 & $<0.01$ & 0.62 \\
\hline $3-5 w k$ & 905 & 1,070 & 1,095 & 1,682 & 73.1 & $<0.01$ & 0.33 \\
\hline $6-9 w k$ & 1,095 & 1,116 & 1,159 & 1,339 & 51.3 & 0.04 & 0.32 \\
\hline 10-13 wk & 1,337 & 1,449 & 1,254 & 1,339 & 39.4 & 0.59 & 0.86 \\
\hline 14-17 wk & 1,348 & 1,550 & 1,615 & 1,507 & 38.0 & 0.11 & 0.05 \\
\hline 18-19 wk & 1,471 & 1,545 & 1,290 & 1,302 & 66.4 & 0.25 & 0.83 \\
\hline Weaning period (0-5 wk) & 847 & 992 & 1,124 & 1,455 & 53.5 & $<0.01$ & 0.02 \\
\hline Growing period (6-13 wk) & 1,216 & 1,283 & 1,207 & 1,339 & 24.7 & 0.17 & 0.48 \\
\hline Finishing period (14-19 wk) & 1,410 & 1,548 & 1,452 & 1,405 & 37.0 & 0.76 & 0.26 \\
\hline Overall period (0-19 wk) & 1,158 & 1,261 & 1,274 & 1,400 & 26.8 & 0.01 & 0.79 \\
\hline $\begin{array}{l}\text { Days to market weight from } 7.01 \mathrm{~kg} \\
\text { (reached } 110 \mathrm{~kg} \mathrm{BW})\end{array}$ & 141.7 & 137.7 & 137.4 & 137.1 & 2.11 & 0.46 & 0.67 \\
\hline Estimated feed cost to $110 \mathrm{~kg}$ (won) & 123,517 & 131,349 & 132,449 & 137,231 & $2,534.9$ & 0.11 & 0.40 \\
\hline
\end{tabular}

SEM, standard error of mean; BW, body weight.

1) Least squares means of 10 replications per treatment. 
pigs and was the most economically efficient.

\section{CONFLICT OF INTEREST}

We certify that there is no conflict of interest with any financial organization regarding the material discussed in the manuscript.

\section{ACKNOWLEDGMENTS}

This research was supported by "Cooperative Research Program for Agriculture Science and Technology Development (Project No. PJ011617012016)" Rural Development Administration, Republic of Korea.

\section{REFERENCES}

1. Wolter BF, Ellis M, Corrigan BP, et al. Impact of early postweaning growth rate as affected by diet complexity and space allocation on subsequent growth performance of pigs in a weanto-finish production system. J Anim Sci 2003;81:353-9.

2. Graham PL, Mahan DC, Shields RG. Effect of starter diet and length of feeding regimen on performance and digestive enzyme activity of 2-week old weaned pigs. J Anim Sci 1981;53: 299-307.

3. Mahan DC, Fastinger ND, Peters JC. Effects of diet complexity and dietary lactose levels during three starter phases on postweaning pig performance. J Anim Sci 2004;82:2790-7.

4. Cromwell GL, Allee GL, Mahan DC. Assessment of lactose level in the mid- to late-nursery phase on performance of weanling pigs. J Anim Sci 2008;86:127-33.

5. Nessmith WB, Nelssen JL, Tokach MD, et al. Evaluation of the interrelationships among lactose and protein sources in diets for segregated early-weaned pigs. J Anim Sci 1997;75: 3214-21.

6. Nessmith WB, Nelssen JL, Tokach MD, Goodband RD, Bergstrom JR. Effects of substituting deproteinized whey and(or) crystalline lactose for dried whey on weanling pig performance. J Anim Sci 1997;75:3222-8.

7. Jin KY. Evaluation of barley to replace milk products in weaning pigs diet. Ph.M. Thesis. Seoul, Korea: Seoul National University; 2013.

8. NRC. Nutrient requirements of swine. 10th ed., Washington, DC, USA: Natl Acad Press; 1998.

9. Hermes RG, Molist F, Ywazaki M, et al. Effect of dietary level of protein and fiber on the productive performance and health status of piglets. J Anim Sci 2009;87:3569-77.

10. AOAC. Official methods of analysis. 16th ed. Assoc. Off. Anal. Chem., Arlington, VA, USA: AOAC International; 1995.

11. SAS. SAS/STAT User's Guide, Version 9.2. Cary, NC, USA: SAS Inst. Inc.; 2009.

12. Coffey RD, Cromwell GL. The impact of environment and antimicrobial agents on the growth response of early-weaned pigs to spray-dried porcine plasma. J Anim Sci 1995;73:2532-9.

13. Maxwell CV, Carter SD. Feeding the weaned pig. In: Lewis AJ, Southern LL, editor. Swine nutrition. Washington, DC, USA: CRC Press; 2001. pp. 691-715.

14. Nessmith WB, Tokach MD, Goodband RD, Nelssen JL. Defining quality of lactose sources used in swine diets. Swine Health Prod 1997;5:145-9.

15. Mavromichalis I, Hancock JD, Hines RH, Senne BW, Cao H. Lactose, sucrose, and molasses in simple and complex diets for nursery pigs. Anim Feed Sci Technol 2001;93:127-35.

16. O'Doherty JV, Nolan CS, McCarthy PC. Interaction between lactose levels and antimicrobial growth promoters on growth performance of weanling pigs. J Sci Food Agric 2005;85:371-80.

17. Shearer LJ, Dunkin AC. Urinary and faecal sugar losses in growing pigs fed diets containing lactose. NZ J Agric Res 1969; 12:321-32.

18. Tokach MD, Pettigrew JE, Johnston LJ, et al. Effect of adding fat and(or) milk product to the weanling pig diet on performance in the nursery and subsequent grow-finish stages. J Anim Sci 1995;73:3358-68.

19. Martínez-Ramírez HR, De Lange CFM. Compensatory growth in pigs. In: Garnsworthy PC, Wiseman J, editors. Recent advances in animal nutrition. Nottingham, UK: Nottingham University Press; 2008. 41:331-54.

20. Ishida A, Nakashima K, Kyoya T, Katsumata M. Mechanism of compensatory growth with changing levels of dietary lysine from deficient to sufficient in pigs. Japan Agric Res Q 2015;49: 23-8.

21. Totafurno AD, Mansilla WD, Wey D, Mandell IB, de Lange CFM. 227 Compensatory body protein gain in newly weaned pigs [abstract]. J Anim Sci 2017;95(Suppl 2):109.

22. Eggum BO. Blood urea measurement as a technique for assessing protein quality. Br J Nutr 1970;24:983-8.

23. Orok EJ, Bowland JP. Rapeseed, peanut and soybean meal as protein supplements: plasma urea concentrations of pigs on different feed intake as indices of dietary protein quality. Can J Anim Sci 1975;55:347-51.

24. Bassily NS, Michael KG, Said AK. Blood urea content for evaluating dietary protein quality. Food/Nahrung 1982;26:75964.

25. Poulsen HD. Zinc oxide for weanling piglets. Acta Agric Sacnd Anim Sci 1995;45:159-67.

26. Mateos GG, Martin F, Latorre, Vicente B, Lazaro R. Inclusion of oat hulls in diets for young pigs based on cooked maize or cooked rice. Anim Sci 2006;82:57-63.

27. Frape DL, Hays VW, Speer VC, Jones JD, Catron DV. The effect of varied feed intake to 8 weeks of age on growth and development of pigs to 200 pounds bodyweight. J Anim Sci 1959;18: 1492.

28. Beilken SL, Bouton PE, Harris PV. Some effects on the mechanical properties of meat produced by cooking at temperatures 
between $50^{\circ} \mathrm{C}$ and $60^{\circ} \mathrm{C}$. J Food Sci 1986;51:791-6.

29. Hamm R. Functional properties of the myofibrillar system and their measurements. In: Bechtel PJ, editor. Muscle as food. London, UK: Academic Press; 1986. pp. 135-99.

30. Maribo H, Olsen EV, Moeller AJ, Karlsson AH. Effect of early post mortem cooling on temperature, $\mathrm{pH}$ fall and meat quality in pigs. Meat Sci 1998;50:115-29.

31. Warris PD. The relationship between $\mathrm{pH}_{45}$ and drip in pig muscle. Int J Food Sci Technol 1982;17:573-8.

32. Monahan FJ, Gray JI, Asghar A, et al. Influence of diet on lipid oxidation and membrane structure in porcine muscle microsomes. J Agric Food Chem 1994;42:59-63.
33. Cheah KS, Cheah AM, Krausgrill DI. Effect of dietary supplementation of vitamin $\mathrm{E}$ on pig meat quality. Meat Sci 1995;39: 255-64.

34. Kauffman RG, Cassens RG, Scherer A, Meeker DL. Variations in pork quality. Des Moines, IA, USA: National Pork Producer Council; 1992.

35. Maganhini MB, Mariano B, Soares AL, et al. Meats PSE (Pale, Soft, Exudative) and DFD (Dark, Firm, Dry) of an industrial slaughterline for swine loin. Food Sci Technol 2007;27:69-72.

36. Bendall JR, Wismer-Pedersen J. Some properties of the fibrillar proteins of normal and watery pork muscle. J Food Sci 1962; 27:144-59. 